\title{
Investigating the existence of asymmetric Environment Kuznets Curve and Pollution-Haven Hypothesis in China: Fresh evidence from QARDL and Quantile Granger Causality
}

\section{Rabia Akram}

Guilin University of Electronic Technology

Zeeshan Fareed ( $\nabla$ zeeshanfareed@hotmail.com )

Huzhou University https://orcid.org/0000-0003-1971-8867

\section{Gan Xiaoli}

Guilin University of Technology

\section{Bushra Zulfiqar}

Southwestern University of Finance and Economics

\section{Farrukh Shahzad}

Guangdong University of Petrochemical Technology

\section{Research Article}

Keywords: Environment Kuznets Curve, Pollution Haven Hypothesis, Quantile ARDL

Posted Date: August 24th, 2021

DOI: https://doi.org/10.21203/rs.3.rs-710446/v1

License: (c) (1) This work is licensed under a Creative Commons Attribution 4.0 International License.

Read Full License 
Investigating the existence of asymmetric Environment Kuznets Curve and PollutionHaven Hypothesis in China: Fresh evidence from QARDL and Quantile Granger Causality

Rabia Akram,

Business School,

Guilin University of Electronic Technology, P.R China

Email: drrabia@guet.edu.cn

*Corresponding Author:

Zeeshan Fareed,

School of Economics and Management,

Huzhou University, Huzhou, Zhejiang, P.R, China

Email: zeeshanfareed@zjhu.edu.cn

\section{Gan Xiaoli}

Business School,

Guilin University of Electronic Technology, P.R China

Email: sallygan@guet.edu.cn

\section{Bushra Zulfiqar,}

School of Economics,

Southwestern University of Finance and Economics, Chengdu, P.R China

Email: bushra_zulfiqar786@hotmail.com

\section{Farrukh Shahzad}

School of Economics and Management,

Guangdong University of Petrochemical Technology, Guangdong, P.R China

Email: farrukh.hailian@gmail.com 


\section{Graphical Abstract}

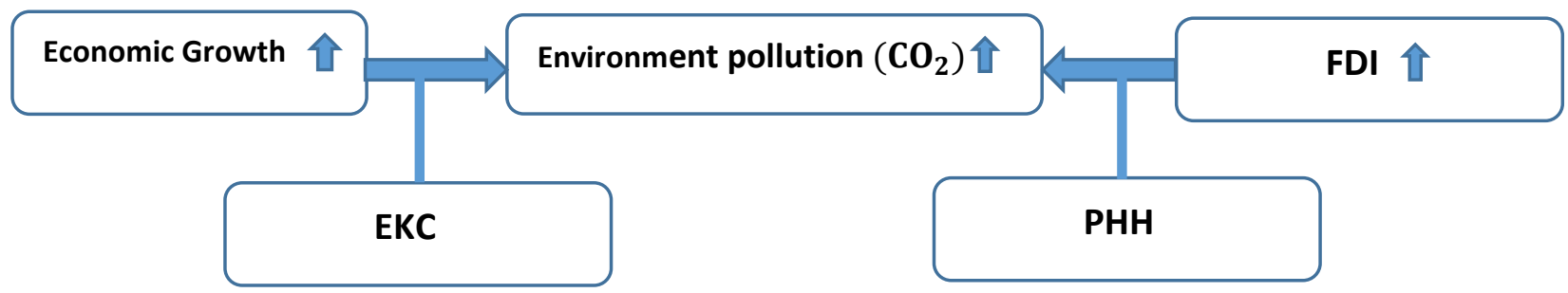

\section{Abstract}

This study aims to analyze the asymmetric long-run relationship between economic growth (EG), Foreign Direct Investment (FDI) and carbon emissions $\left(\mathrm{CO}_{2}\right)$ within the context of the Environment Kuznets curve (EKC) and the pollution haven hypothesis $(\mathrm{PHH})$ in China. Employing the quarterly data from 1982Q1 to 2018Q4, we have used novel techniques to meet the stated objectives of our study, named Quantile ARDL and quantile Granger causality. The significant implication of this method is that it provides locational asymmetry. We find strong evidence of the EKC and $\mathrm{PHH}$ for China based on the empirical results of linear and nonlinear ARDL models. Similarly, findings of quantile Granger causality validate the bidirectional relationship among all variables in upper and lower quantiles. Moreover, the results of the Wald

71 test confirm the asymmetric long-run relationship between FDI and carbon emissions $\left(\mathrm{CO}_{2}\right)$. This

72 study will be conducive for the policymakers to combat environmental contamination concerning 73 economic growth and FDI inflow in China.

74 Keywords: Environment Kuznets Curve, Pollution Haven Hypothesis, Quantile ARDL 


\section{Introduction:}

77 Several changes are made in global policy after the emergence of WTO. The purpose was to reduce

78 the divergence between rich and poor countries by removing the tariff and non-tariff barriers

79 Murthy and Gambhir (2018). The effect of international trade on the environment has been

80 discussed broadly since 1970 . This debate became more severe in 1990, after trade openness by

81 various organizations (NAFTA, UNCED, and WTO) ${ }^{1}$. Thus, global pollution distribution has

82 emerged as an important policy question in the environmental economics literature (Gill et al.,

83 2018a). Currently, China is the second-biggest economy of the world, and it has encountered rapid

84 economic development in recent years because of economic reforms (World energy outlook,

85 2010). China has achieved remarkable economic expansion accompanied by extensive

86 environmental pollution. The massive ecological damage has forced China to build an

87 environment-friendly society by introducing costly environmental policies (Wang et al., 2018).

88 China fast economic growth (EG) has made it a heated topic in the whole world. The economists

89 and researchers are interested in knowing whether the environment in China will worsen or

90 improve if the economy follows the increase in per capita income. The Per capita GDP of China

91 has improved from US\$ 227 in 1978 to US\$8109 in 2015, along with massive emission of

92 environmental pollution (27\%) (Mundial, 2007). In this domain, the critical empirical foundation

93 is the Environment Kuznets curve (EKC) hypothesis, introduced by Grossman and Krueger

94 (1991). EKC hypothesis suggests that environmental degradation increases at early phases of

95 economic growth, and it turns to decrease as income reaches a certain threshold level.

\footnotetext{
${ }^{1}$ NAFTA is the North American Free Trade Agreement. UNCED is the United Nations Conference on Environment and Development also known as "Earth Summit". WTO refers to World Trade Organization.
} 
Another critical hypothesis related to environmental deterioration is the Pollution Haven

97 Hypothesis (PHH). The PHH explains that the developed countries migrate their dirty industries

98

99

100

101

102

103

104

105

106

107

108

109

110

111

112

113

114

115

116

117

118

to the developing countries (Gill et al., 2018a) and raise their pollution intensity. China has become the most appealing target for FDI since after trade opens up policy. During the 1990s, China was the next primary recipient of FDI after the USA and the principal beneficiary of FDI in the developing countries (He, 2006). After 2000 China became the most compelling FDI receiver nation for precious assets, cheap labour price, and lax environmental regulations.

On the other hand, carbon emissions are increasing rapidly in China. China has also become the largest producer of regional fossil fuel CO2 emissions since 2006, as displayed in Table 1. China is now confronting enormous pressure from the international society to control carbon emissions. So China has become a haven for dirty industries of advanced countries, leading to the Pollution Haven Hypothesis in China (Sun et al., 2017). Figure 1 shows the behaviour of time series variables over time.

\section{[INSERT FIGURE 1 HERE]}

\section{[INSER TABLE 1 HERE]}

Though in the previous two decades, the EKC has been rigorously examined, the empirical findings seem to be questionable as some studies exhibit the inverted U-shaped EKC (see, e.g.,AlMulali et al., 2015b; Apergis et al., 2018; Cheng et al., 2017; Destek \& Sarkodie, 2019; Salman et al., 2019; Zhu et al., 2016a), some suggest the N-shaped (see, e.g.,Allard et al., 2018; Hao et al., 2018) and inverted N-shaped (see, e.g.,Liu \& Lin, 2019; Özokcu \& Özdemir, 2017). Similarly, there are inconclusive results about the existence of $\mathrm{PHH}$ in China because some studies provide evidence of PHH (see, e.g.,Acharyya, 2009; He, 2011; He \& Yao, 2017; Sun et al., 2017; Xiao, 2015) while, some studies do not support the PHH in China (see, e.g.,Sarkodie \& Strezov, 2019; 
119

120

121

122

123

124

125

126

127

128

129

130

131

132

133

134

135

136

137

138

139

140

141

Xiao, 2015; Zhang \& Zhou, 2016). The reason is that existing literature varies a lot in terms of sample and methodologies.

The related literature in China in terms of the sample can be categorized into three groups, research on time series data (see, e.g.,Jalil \& Feridun, 2011; Jalil \& Mahmud, 2009; Sun et al., 2017; Xiao, 2015; Zhang \& Zhou, 2016). They have focused on Chinese aggregate data to estimate the EKC. The second strand of literature comprises panel data of China with other countries (see, e.g.,Govindaraju \& Tang, 2013; Pao \& Tsai, 2010, 2011; Sarkodie \& Strezov, 2018a; Zakarya et al., 2015). They have compared the china with other countries. While, (see, e.g.,Cheng et al., 2017; He, 2011; He \& Yao, 2017; Liu \& Lin, 2019; Wang et al., 2017; Wang et al., 2019) have treated with the panel of Chinese provinces or cities.

Existent literature has also used different methodologies. Mostly the studies with aggregate data have used the Autoregressive distributed lagged (ARDL) model (see, e.g.,Hakimi \& Hamdi, 2016; Jalil \& Mahmud, 2009). While Jalil and Feridun (2011) have combined the ARDL with bounds testing procedure, Shahbaz et al. (2015) have also employed the ARDL bound test. Acharyya (2009) and Wang et al. (2011) have also applied the cointegration regression analysis. Some researchers have also combined the cointegration analysis along with ARDL. Al-Mulali et al. (2015a) and Xu (2018) have employed VECM and ARDL. Hakimi and Hamdi (2016) used a vector error correction mechanism (VECM) and cointegration analysis. Cole et al. (2011) have used the fixed effect panel data model, Neequaye and Oladi (2015) have used the Instrumented FE model, Tamazian and Rao (2010) have used the generalised method of moments (GMM), Özokcu and Özdemir (2017) have used panel data techniques with Driscoll-Kraay Standard Errors while some studies have applied the spatial econometrics analysis. Hao et al. (2018) and Liu and Lin (2019) have implemented the spatial panel models SLM, SEM, SDM, Cheng et al. (2017) have used 
142 Dynamic spatial panel model. Wang et al. (2017) and Zhang and Zhou (2016) have used the 143 (STIRPAT) model. For more details, see Table 2.

144 The critical review on the nexus between $\mathrm{EG}$ and $\mathrm{CO}_{2}$ emissions reveal that linear models have 145 been applied extensively. While Po and Huang (2008) argue that linear models cannot explain the 146 long-term relationship between time series variables due to short-term fluctuations and structural 147 change. Similarly, Anoruo (2011) explains that linear models can only capture linear relationships 148 while most time series variables exhibit nonlinear behaviour. Dutta et al. (2019) also claim that 149 linear models show conflicting results while observing a volatile series, which could be due to the 150 nonlinear behaviour of the variables. Kahneman and Tversky (2013) emphasise the importance of 151 asymmetric modelling. Behmiri and Manera (2015) and Kumar (2017) discuss that the nonlinear 152 structure of economic and financial time series can be due to economic situations. Besides, they 153 comment that economic and financial variables generally exhibit nonlinear behaviour due to 154 economic instability and crisis; hence, nonlinear models are required to capture the volatility of 155 time series data.

156 Different from the existing literature, we consider the potential nonlinear association between EG, 157 FDI and $\mathrm{CO}_{2}$ emissions and apply the Quantile autoregressive distributed lag (QARDL) model 158 proposed by Cho et al. (2015). This study aims to analyse the asymmetric long-run relationship 159 between EG, FDI and $\mathrm{CO}_{2}$. Within the context of the EKC and $\mathrm{PHH}$ in China. To meet the stated 160 objectives of our study, we have used a novel technique employing the quarterly data from 1982Q1 161 to 2018Q4. This approach has some benefits as compared to alternate methods. Firstly it offers a 162 more flexible econometric structure to test the strength of long term association across quantiles 163 by testing cointegration between $\mathrm{I}(0)$ and $\mathrm{I}(1)$ variables. Thus it reduces the constraint of the 164 Johansen cointegration test, which requires all the time series in the system I(1) (Lahiani et al., 
165 2018). Secondly, it also relaxes the condition of normality and provides a robust conclusion.

166 Thirdly, it allows estimating the cointegration between the $\mathrm{CO}_{2}$ emissions and decisive factors for

167 the whole distribution rather than the conventional measures that emphasise the mean value. The

168 traditional measures may not be as explanatory as QARDL (Zhu et al., 2016b). Moreover, the

169 QARDL provides locational asymmetry. It allows analysing the asymmetric short and long term

170 impact of EG and FDI on $\mathrm{CO}_{2}$ emissions. So the QARDL is an excellent choice to precisely model

171 the nonlinear and asymmetric connections between EG, FDI and $\mathrm{CO}_{2}$ emissions.

172 The rest of the paper is arranged as follows: section two explores the brief literature; section three

173 describes the methodology and data source; section four is dedicated to Empirical results and

174 discussion. Finally, section 5 concludes the paper and offers some policy implications.

175

176 2. Literature Review

177 The literature on the environment is extensive, and it can be mapped out from the pioneering work 178 of Baumol (1971) and Crocker (1966). Our study is closely linked with two divisions of literature:

179 one is the association between economic growth and environment deprivation EKC (see, e.g., 180 Destek \& Sarkodie, 2019; Salman et al., 2019; Sarkodie \& Strezov, 2018b) and the other is the 181 PHH (see, e.g.,Sun et al., 2017; Xiao, 2015).

\section{$182 \quad 2.1 \quad$ The Environment Kuznets Curve Hypothesis (EKC):}

183 A compelling argument in the economics literature is the association between EG and 184 environmental deterioration named EKC. It was the first to raise a voice against "too poor too 185 green", which suggests that the developing nations cannot control the environmental issues 186 appropriately because of insufficient resources. Only rich countries can protect their environment 187 because they can plant clean technologies to control environmental problems. Gill et al. (2018a) 
and Grossman and Krueger (1991) exhibit that economic growth is useful to reduce environmental destruction. Further, they demonstrate that gains from trade could not be as dangerous for the climate as anticipated. Extensive research has been carried out on the environment - growth nexus after the Grossman and Helpman (1993) and Grossman and Krueger (1991), but the results are complex. These studies have found that economic growth is helpful to overcome environmental problems (Ozturk \& Acaravci, 2010; Sari \& Soytas, 2007; Zhang et al., 2018). Brajer et al. (2011) has used the three comprehensive indexes of pollution along with individual pollution measures and concluded that EKC depends on the form of environment indicator. Though the results show some support to inverted U-shaped EKC, the study has found some strong conflicting effects. Azomahou et al. (2006) have employed a panel of 100 countries; their findings also do not support the conventional EKC instead confirm an upward slope relation between income and per capita pollution. Similarly, some studies have found no affirmation for the existence of conventional EKC (Al-Mulali et al., 2015a; Ngarambe et al., 2018; Ozturk \& Acaravci, 2010; Pao \& Tsai, 2011; Xu, 2018; Zhu et al., 2016a)

However, extensive empirical literature determines the evidence of the EKC hypothesis. Stern and Common (2001) used a more comprehensive sample. They found the inverted U-shaped association between per capita sulfur emanations and per capita income within a sample of highincome states. Similarly, Ozturk and Al-Mulali (2015) have used the panel data of Cambodia and found the existence of EKC. Kharbach and Chfadi (2017) have also determined the reversed Ushaped association between GDP and $\mathrm{CO}_{2}$ emissions in the transportation division of Morocco. Galeotti et al. (2006) and Vollebergh and Kemfert (2005) have also stated the existence of EKC by employing diverse countries data and by using the $\mathrm{CO}_{2}$ emissions as environment indicator. Moreover, following studies have also estimated the traditional EKC (Al-Mulali et al., 2015b; 
211 Ang, 2007; Apergis et al., 2018; Cheng et al., 2017; Destek \& Sarkodie, 2019; Neequaye \& Oladi,

212 2015; Salman et al., 2019; Sarkodie \& Strezov, 2018a; Shahbaz et al., 2015; Wang et al., 2017).

213 Allard et al. (2018) and Hao et al. (2018) have examined an N-shaped EKC. While Liu and Lin

214 (2019) and Özokcu and Özdemir (2017) demonstrate the reversed N-shaped association between

215 environment and per capita income.

\section{2.2 The Pollution Haven Hypothesis (PHH) and environment:}

217 The PHH unfolds that due to stringent environmental policies, the developed countries migrate

218 their dirty industries to the developing countries. They take benefit of the fragile environmental

219 laws of developing nations and raise their pollution. This phenomenon is observed under the

220 comparative cost theory when developed nations concentrate on the manufacturing and export of

221 clean products, and the developing countries emphasise the production and export of dirty goods;

222 thus, developing states grow into the pollution heaven for the dirty industries of developed nations

223 (Gill et al., 2018b). The empirical research has exposed that different environmental regulations

224 have different implications. Xu (1999) has observed that exports of environmentally sensitive

225 goods (ESGs) remain unchanged by introducing stringent environmental regulations. While in

226 some circumstances, rigorous environmental regulations can reduce competitiveness. Low and

227 Yeats (1992) have explored that developing economies gain a comparative advantage in the

228 manufacturing of ESGs more than the industrialized countries because of weak environmental

229 regulations.

230 Another critical factor that affects the environment is foreign direct investment (FDI). The

231 previous empirical evidence about the effect of FDI on the environment are inconclusive (Zhang

$232 \&$ Zhou, 2016). Some studies found the positive impact of FDI on the climate of the host country.

233 Their view is FDI promotes cleaner technology and improvement in energy efficacy, so it helps to 
234 improve the host country's environment (Sun et al., 2017). Eskeland and Harrison (2002) have 235 examined the FDI framework in four developing states: Cote d'Ivoire, Mexico, Morocco, and 236 Venezuela and found that though international firms are located in high air pollution regions of 237 developing countries, they produce less pollution than foreign firms use more energy effective 238 technology and apply cleaner energy sources as compared to their peer. Al-Mulali and Tang (2013) 239 also conclude that FDI helps to reduce $\mathrm{CO}_{2}$ emissions in the GCC countries. Thus PHH does not 240 confirm. Likewise, Zhang and Zhou (2016) have used the Chinese provincial-level data and 241 deduced that FDI brings a reduction in $\mathrm{CO}_{2}$ emissions in China. Tamazian et al. (2009) have 242 analysed that trade openness and financial development tend to decrease the environmental 243 degradation in BRICS counties. Moreover, Wang et al. (2019) have found no evidence of PHH in 244 the domestic trade of China.

245 Likewise, Javorcik and Wei (2004) have found some weak evidence of PHH on 24 Transition 246 Economies. They have identified that the absence of some essential features (such as bureaucratic 247 corruption) in the host country leads to ambiguous results. Cole and Elliott (2005) have 248 investigated that it is not only the lax environment regulations that cause $\mathrm{PHH}$, but factor 249 endowment is also essential to determine PHH. High capital abundant countries are more likely to 250 experience PHH.

251 While the studies which found the negative impact of FDI on host countries claim that trade 252 openness aggravates the market competition. It forces some of the developing countries to limit 253 their environmental regulations to invite FDI, so the environmental condition of the host country 254 declines due to FDI inflows. Sun et al. (2017) and Hitam and Borhan (2012) have found that FDI 255 is a cause of climate worsening in Malaysia. Hoffmann et al. (2005) have employed the data of 256112 nations and found the adverse effect of FDI on the environment of low-income countries 
257 because low-income countries are less proficient at executing and scrutinising the environmental 258 regulations. They conclude that the existence of $\mathrm{PHH}$ depends on the level of growth of the host 259 country. Similarly, Lee (2013) has examined that FDI increases the economic growth in G20 260 countries but the increase in $\mathrm{CO}_{2}$ emissions limit its decisive role. Al-mulali (2012) have also 261 concluded that FDI contributes to increase $\mathrm{CO}_{2}$ emissions in Middle East countries.

[INSERT TABLE 2 HERE]

263

264 3. Empirical Methodology and Data

$2653.1 \quad$ Methodology:

266 We are closely following the methodology of Lahiani et al. (2018) and Shahbaz et al. (2018). The 267 EKC hypothesis suggested by Grossman and Krueger (1991) in its general form can be written as 268 follows:

$$
\mathrm{CO}_{2}=f\left(y, y^{2}, V\right)
$$

270 Here $\mathrm{CO}_{2}$ is environment indicator, y is GDP, and $\mathrm{V}$ refers to other explanatory variables that may 271 affect the environmental deterioration. We have also included foreign trade in our model to avoid 272 omitted variable bias (Halicioglu, 2009). The FDI variable is also incorporated to evaluate the 273 effect of FDI on environmental pollution as proposed by PHH (Walter \& Ugelow, 1979). We 274 estimate the following regression equation in the logarithmic form:

$$
\operatorname{lnCO} O_{t}^{2}=\alpha_{0}+\alpha_{1} \ln G D P_{t}+\alpha_{2} \ln G D P_{t}^{2} \alpha_{3} \ln F D I_{t}+\alpha_{4} \ln \operatorname{Trade}_{t}+\varepsilon_{t}
$$

276 where $\mathrm{t}$ refers to the period, $\mathrm{CO}_{2}$ is per capita carbon emission, GDP is per capita gross domestic 277 product, FDI is foreign direct investment, Trade is the sum of imports and exports, and $\varepsilon_{t}$ is the 
278 standard error term. If $\alpha_{1}<0$ and $\alpha_{2}>0$ it represents the $\mathrm{U}$-shaped association between $\mathrm{CO}_{2}$

279 and GDP, if $\alpha_{1}>0$ and $\alpha_{2}<0$ it follows an inverted U-shaped curve. Thus, EKC holds.

280 Since the nonlinear and asymmetric relationship between EG, FDI and $\mathrm{CO}_{2}$ emissions are now 281 acknowledged, we employ the recently developed QARDL model proposed by Cho et al. (2015)

282 to explore the association between $\mathrm{CO}_{2}$ emissions, $\mathrm{EG}$ and FDI. We perform the following steps

283 in this study. First, we find the stationarity to identify the order to integrate variables by applying

284 unit root tests. Secondly, we investigate the long-run equilibrium relationship by using the ARDL

285 model. Third, we extend the ARDL model to the QARDL model setting to explore further the 286 quantile long-run equilibrium correlation between variables of interest. Then we apply the Wald 287 test to check the constancy of our parameters of concern.

288 3.1.1 QARDL model: We employ the newly established QARDL model proposed by (Cho et al., 289 2015) to explore the nonlinear behavior of $\mathrm{EG}$ and $\mathrm{FDI}$ on $\mathrm{CO}_{2}$ emissions that refer to the EKC 290 and PHH in the context of China. The benchmark ARDL model, as examined in (Pesaran et al., 291 2001) is written as:

292

$\mathrm{CO} 2_{\mathrm{t}}=\alpha+\sum_{i=1}^{p} \varphi_{i} \mathrm{CO} 2_{\mathrm{t}-1}+\sum_{i=0}^{q 1} \omega_{i} G D P_{t-i}+\sum_{i=0}^{q 2} \vartheta_{i} G D P_{t-i}^{2}+\sum_{i=0}^{q 3} \theta_{i} F D I_{t-i}+\sum_{i=0}^{q 4} \delta_{i} T R A D E_{t-i}$$$
+\epsilon_{t}
$$

$294 \epsilon_{t}$ refers to the error term, which is defined as $\mathrm{CO}_{\mathrm{t}}-\left[\mathrm{CO} 2_{\mathrm{t}} / £_{t-1}\right]$ and $£_{t-1}$ being the lowest $295 \sigma-$ field created by $\left[\mathrm{CO}_{\mathrm{t}}, \mathrm{GDP}_{\mathrm{t}}, \mathrm{GDP}_{\mathrm{t}}^{2}, F D I_{t}, T R A D E_{t}, \mathrm{CO}_{\mathrm{t}-1}, \mathrm{GDP}_{\mathrm{t}-1}, \ldots ..\right]$ besides $p, q_{1}$, $296 q_{2}, q_{3}, q_{4}$ are lag orders in the model determined Bayesian information criteria (BIC).. 
297 We formalise the following $\operatorname{QARD}(p, q)$ model by extending the model (1) in a quantile setting, 298 as suggested by (Cho et al., 2015).

299 $Q_{\triangle C O 2_{t}}=\alpha(\tau)+\sum_{i=1}^{p} \varphi_{\mathrm{i}}(\tau) \mathrm{CO}_{\mathrm{t}-\mathrm{i}}+\sum_{\mathrm{i}=0}^{\mathrm{q} 1} \omega_{\mathrm{i}}(\tau) \mathrm{GDP}_{\mathrm{t}-\mathrm{i}}+\sum_{\mathrm{i}=0}^{\mathrm{q} 2} \vartheta_{i}(\tau) G D P_{t-i}^{2}+\sum_{i=0}^{q 3} \theta_{i}(\tau) F D I_{t-i}$ $+\sum_{i=0}^{q 4} \delta_{i}(\tau) T R A D E_{t-i}$

302 Here $\epsilon_{t}(\tau)$ indicates the error term that is described as $\operatorname{CO}_{t}-Q_{\triangle C O 2_{t}}\left(\tau / £_{t-1}\right)$ and $303 Q_{\triangle \mathrm{CO}_{t}}\left(\tau / £_{t-1}\right)$ is the $\tau-$ th quantile of $C O 2_{t}$ depends on the information set $£_{t-1}$ (Kim \& 304 White, 2003) and $0<\tau<1$.

305 To avoid the potential autocorrelation in the error term, we generalise the QARDL model in Eq(2) 306 as follows:

$$
\begin{aligned}
Q_{\triangle C O 2_{t}}=\alpha(\tau) & +\rho \mathrm{CO} 2_{\mathrm{t}-1}+\gamma_{\mathrm{gdp}} \mathrm{GDP}_{\mathrm{t}-1}+\gamma_{\mathrm{gdp}^{2}} \mathrm{GDP}_{\mathrm{t}-1}^{2}+\gamma_{\mathrm{fdi}} \mathrm{FDI}_{\mathrm{t}-1}+\gamma_{\mathrm{trade}} \mathrm{TRADE}_{\mathrm{t}-1} \\
& +\sum_{\mathrm{i}=1}^{\mathrm{p}} \varphi_{\mathrm{i}}(\tau) \Delta \mathrm{CO} 2_{\mathrm{t}-\mathrm{i}}+\sum_{\mathrm{i}=0}^{\mathrm{q} 1} \gamma_{\mathrm{i}}(\tau) \Delta \mathrm{GDP}_{\mathrm{t}-\mathrm{i}}+\sum_{\mathrm{i}=0}^{\mathrm{q} 2} \lambda_{\mathrm{i}}(\tau) \Delta \mathrm{GDP}_{\mathrm{t}-1}^{2} \\
& +\sum_{i=0}^{q 3} \theta_{i}(\tau) \Delta F D I_{t-i}+\sum_{i=0}^{q 4} \pi_{i}(\tau) \Delta T R A D E_{t-i} \\
& +\epsilon_{\mathrm{t}}(\tau)
\end{aligned}
$$

311 The above eq(3) can be expressed to assign the ECM parameters of the QARDL model (Cho et 312 al., 2015). 

estimated as $\gamma_{*}=\sum_{\mathrm{i}=0}^{\mathrm{q} 1-1} \omega_{\mathrm{i}}, \quad \lambda_{*}=\sum_{\mathrm{i}=0}^{\mathrm{q} 2-1} \vartheta_{\mathrm{i}}, \theta_{*} \sum_{\mathrm{i}=0}^{\mathrm{q} 3-1} \theta_{\mathrm{i}}, \pi_{*}=\sum_{\mathrm{i}=0}^{\mathrm{q} 4-1} \delta_{\mathrm{i}}, \quad$ separately. The

323 long-run cointegration parameters for GDP, GDP ${ }^{2}$, FDI and Trade are calculated as

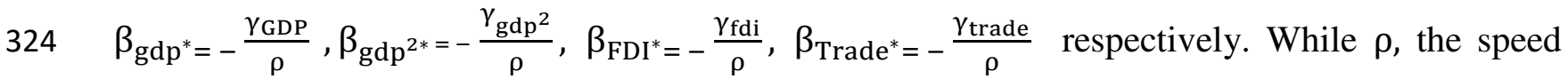
325 adjusting parameter is required to be negative and significant.

326

327

328 and short-run asymmetry effect, respectively:

329

$330 \quad$ against the alternative hypothesis $\forall i \neq j$ or $\beta(i) \neq \beta(j)$

$331 H_{0}^{S}=\varphi(0.05)=\varphi(0.1)=\cdots=\varphi(0.95)$

$$
\begin{aligned}
\mathrm{Q}_{\mathrm{CO}} 2_{\mathrm{t}}=\alpha(\tau) & +\rho(\tau)\left(\mathrm{CO}_{\mathrm{t}-\mathrm{i}}-\beta_{\mathrm{gdp}}(\tau) \mathrm{GDP}_{\mathrm{t}-1}-\beta_{\mathrm{gdp}^{2}}(\tau) \mathrm{GDP}_{\mathrm{t}-1}^{2}-\beta_{\mathrm{fdi}}(\tau) \mathrm{FDI}_{\mathrm{t}-1}\right. \\
& \left.-\beta_{\text {trade }}(\tau) \mathrm{TRADE}_{\mathrm{t}-1}\right) \\
& +\sum_{\mathrm{i}=1}^{\mathrm{p}-1} \varphi_{\mathrm{i}}(\tau) \Delta \mathrm{CO} 2_{\mathrm{t}-\mathrm{i}}+\sum_{\mathrm{i}=0}^{\mathrm{q} 1-1} \gamma_{\mathrm{i}}(\tau) \Delta \mathrm{GDP}_{\mathrm{t}-\mathrm{i}}+\sum_{\mathrm{i}=0}^{\mathrm{q} 2-1} \lambda_{\mathrm{i}}(\tau) \mathrm{GDP}_{\mathrm{t}-1}^{2} \\
& +\sum_{i=0}^{q 3-1} \theta_{i}(\tau) \Delta F D I_{t-i}+\sum_{i=0}^{q 4-1} \pi_{i}(\tau) \Delta T R A D E_{t-i} \\
& +\epsilon_{\mathrm{t}}(\tau)
\end{aligned}
$$

The aggregate short period effect of the past $\mathrm{CO}_{2}$ emissions on current $\mathrm{CO}_{2}$ emissions are estimated as $\varphi_{*}=\sum_{i=1}^{p-1} \varphi_{i}$ while the aggregate short term effect of the contemporary and previous gross domestic product, the square of GDP, FDI and trade on the current level of $\mathrm{CO}_{2}$ emissions are

26 Further, we employ the Wald test to examine the short and long-run asymmetric (nonlinear) effect 27 of GDP growth and FDI on $\mathrm{CO}_{2}$ emissions. We consider the following null hypothesis for long

(a)

$H_{0}^{L}=\beta(0.05)=\beta(0.1)=\cdots=\beta(0.95)$ 
334 We have selected China by following the accumulation of air pollution index to explore the 335 asymmetric behavior of EG and FDI on the $\mathrm{CO}_{2}$ emissions to validate the existence of EKC and 336 PHH. We have used the quarterly data from 1982Q1 to 2018Q4. The annual data from 1982 to 3372018 are used and transformed into quarterly data using the quadratic match-sum principle 338 (Lahiani et al., 2018). This method is useful to adjust cyclical fluctuations in data, and its 339 application is also quite simple (Arain et al., 2019). All the variables are taken from World Bank 340 (2018). Table 3 reports the definitions of the variables and data sources. Table 4 presents the 341 descriptive statistics and results of Unit root tests.

342 Before proceeding for the QARDL model, it is essential to test the order of integration of the time 343 series variables. Thus, we perform the Augmented Dicky-Fuller and (Zivot \& Andrews, 2002) 344 (ZA) unit root tests. The advantage of the ZA test is that it allows for a structural break in the data. 345 The test results of ADF and ZA reveal that only GDP and GDP 2 are stationary at the level I(0) 346 while remaining all other time series $\left(\mathrm{CO}_{2}, F D I\right.$, Trade $)$ are stationary at the first difference, 347 indicating that they are I(1). So, we can apply the QARDL model.

[INSERT TABLE 3 HERE]

[INSERT TABLE 4 HERE]

[INSERT TABLE 5 HERE]

\section{Results and discussion:}

\subsection{Quantile Unit root Test:}


353 For detailed analysis, we have also performed the quantile unit root test to check the order of 354 integration at different quantiles. Table 5 reports the results of the quantile unit root test. The

355 results indicate that we accept the null hypothesis of unit root at a $5 \%$ significance level for all 356 variables except the FDI, which is stationary at Q40, Q50, Q60 and Q79. So overall, the results of 357 the quantile unit root test are consistent with the findings of ADF and ZA tests, and we conclude 358 that our variables are stationary at $\mathrm{I}(\mathrm{I})$.

3594.2 Quantile ARDL results:

360 The results of linear and quantile ARDL are stated in table 6. In section A, the results of the ARDL 361 model indicate a strong cointegration between $\mathrm{CO}_{2}$ emissions and EG. Results specify a significant 362 positive impact of GDP on carbon emissions. While a strong negative significant sign of GDP 2 363 indicates the existence of EKC in China. The findings align with previous literature (Dong et al., 364 2018a; Dong et al., 2018b; Sarkodie \& Strezov, 2018a; Wang et al., 2017). They have found similar 365 results in China. The verdicts state that environmental quality depletes in the initial phases of 366 economic expansion, while in later phases, pollution reduces in China. Since China has achieved 367 remarkable economic growth in a couple of past years, together, China was also the massive 368 emitter of environmental pollution (27\%) (Mundial, 2007).

371 China is now following strict environmental goals to meet with the Paris agreement. Moreover, it 372 had already achieved its target of low carbon emissions per unit of GDP by $46 \%$ from the 2005 373 level, realising its promise before 2020 (United Nations, 2018). So our findings support the EKC 374 hypothesis in China. The significant negative sign of the speed of adjustment parameter " $\rho "$ 
375 confirms the consistency of the estimation of the ARDL model. The past volatility of carbon

376 emissions has an accumulated positive and significant influence on the current values of carbon

377 emissions. The long-run positive and significant impact of FDI on $\mathrm{CO}_{2}$ emissions support the

378 existence of PHH in China. The results are consistent with the findings of (He \& Yao, 2017; Sun

379 et al., 2017; Xiao, 2015). They have found similar results in China. While this phenomenon can

380 be described by the assertion that the amount of FDI grew rapidly in China after the "Opening UP

381 Reforms" and China is now the second-largest recipient of FDI after the USA. Despite being the

382 largest developing country, the standard environment regulations are quite fragile in China 383 compared to the developed world (Zheng \& Sheng, 2017). After "Opening Up and Reforms"

384 China's $\mathrm{CO}_{2}$ emissions have increased rapidly from 780726 Kilo Tons (KT) in 1960 to 10291926

385 (KT) in 2017, and China accounts for 30\% of global carbon emissions (Tollefson, 2017).

386 Moreover, the secondary industry holds a considerable proportion in foreign direct investment of

387 China, while the industrial production and power generation divisions are the record carbon 388 releasing zones ( $85 \%$ of total $\mathrm{CO}_{2}$ emissions) in China (Sun et al., 2017). The long-run impact of 389 international trade on $\mathrm{CO}_{2}$ emissions are positive and significant, signifying that trade openness 390 causes environmental degradation. The results are aligned with the findings of Allard et al. (2018), 391 Jalil and Feridun (2011) and Ozturk and Acaravci (2013) and also support the Grossman and 392 Krueger (1995) argument that developing countries incline to have heavy polluting industries with 393 a large part of pollutions.

394 As Linear ARDL model does not address the asymmetry short and long-run impact of GDP, FDI 395 and trade on $\mathrm{CO}_{2}$ emissions, while the QARDL model considers the locational asymmetry. The 396 results of QARDL in section (B) exhibit that ECM parameter " $\rho$ " is significantly negative at all 397 quantiles (except q05, q10, q20 and q30). The long-run cointegration parameter $\beta_{\mathrm{gdp}}\left(\beta_{\mathrm{gdp}^{2}}\right)$ is 
positive (negative) and significant at all quantiles (except q05 and q10) confirms the existence of EKC in China. It also proves the asymmetry effect of economic growth on $\mathrm{CO}_{2}$ Emissions. While the long-run integration parameter $\beta_{\mathrm{fdi}}$ is positive and significant at higher quantiles (q60, q70 and q80 and q90) supports the validity of PHH in China. For short-run analysis, the accumulated influence of past variations of $\mathrm{CO}_{2}$ Emissions on their current level are positive at all quantiles with one and two time lags. The short-run accumulated effect of past and current GDP (GDP ${ }^{2}$ ) is positive (negative) at lower quantiles. Moreover, the accumulative impact of past and present variations of trade on $\mathrm{CO}_{2}$ emissions are positive.

From Table 7, the Wald test rejects the null hypothesis of linearity for the speed of adjustment parameter, while it fails to reject the null hypothesis of parameter constancy of long-run cointegration parameters $\beta_{\mathrm{gdp}}, \beta_{\mathrm{gdp}}{ }^{2}, \beta_{\text {trade, }}$ Moreover, the test results indicate that past $\mathrm{CO}_{2}$ emissions influence current $\mathrm{CO}_{2}$ emissions asymmetrically at one and two periods lag only. In a nutshell, we only found a non-linearity in the PHH while our study fails to provide asymmetric behavior of EKC in China.

\subsection{Quantile Granger Causality}

Table 8 (Figure 2) indicate the results of the quantile Granger causality approach. We have used equally grid of 11 quartiles pattern, that is $[0.05,0.10,0.20,0.30,0.40,0.50,0.60,0.70,0.80$, 0.90, 0.95]. Findings show that GDP \& $\mathrm{GDP}^{2}$ do Granger cause $\mathrm{CO} 2$ in middle quantiles while $\mathrm{CO} 2$ does Granger cause GDP \& GDP ${ }^{2}$ in upper and lower quantiles. Therefore, results show some support to inverted U-shaped EKC in most of the quantiles. Though, China is the world top CO2 emitter country using green technology to combat environmental pollution. Similarly, FDI does Granger cause $\mathrm{CO} 2$ (and vice versa) in upper and middle quantiles, which validate the pollution 
420 heaven hypothesis. Finally, trade does Granger cause CO2 in middle quantiles while CO2 does

421 Granger cause trade in upper quantiles only.

422 Conclusion and policy recommendations:

423 This study is an effort to observe EKC and $\mathrm{PHH}$ in the Chinese framework as China is undergoing

424 high economic growth and massive FDI inflow while confronting the severe issue of

425 environmental degradation. The paper investigates the quantile long-run relationship between

426 economic growth, $\mathrm{CO}_{2}$ emissions and foreign direct investment based on the EKC hypothesis and

427 PHH for China using quarterly data during 1982Q1 to 2018Q4. We have used a novel technique

428 to meet the stated objectives of our study, named a Quantile ARDL approach. The significant

429 implication of this method is that it provides locational asymmetry. It analyses the asymmetric

430 short- and long-term impact of economic growth and FDI on carbon emissions. The study finds

431 strong evidence of the EKC hypothesis for China as the results of linear ARDL and quantile ARDL

432 models strongly suggest the existence of an inverted U-shaped relationship between economic

433 growth and $\mathrm{CO}_{2}$ emissions. The findings also support the evidence of $\mathrm{PHH}$ in China. Moreover,

434 the QARDL results confirm the significant asymmetric effect of GDP and FDI on $\mathrm{CO}_{2}$ emissions

435 in China in the long run. Similarly, the findings of quantile Granger causality validate the EKC

436 and $\mathrm{PHH}$ in China. Hence, being the most $\mathrm{CO} 2$ emitter country globally and with quick economic

437 progress, China uses green technology to address environmental pollution.

438 Although in some provinces of China, high legislative measures have been adopted for the 439 upgrading of cleaner production. These legal measures must be enhanced, accepted, rigorously 440 imposed and monitored in the remaining provinces to assure a further reduction in carbon 441 emissions. The environment regulations must be restricted further and harmonised to improve their 442 efficiency adequately. The current research has used the aggregate data on China for EKC analysis, 
so inferences cannot be generalised on individual provinces. Though the research reveals that environmental quality improves at higher income levels, the inverted U-shaped EKC of China relies on the income ranks of urban citizens who readily pay for environmental protection. At the same time, the rural people with low earnings are a consistent cause of environmental aggravation.

The study can be extended further to analyze province-level EKC and $\mathrm{PHH}$.

Ethical Approval

Manuscript does not report on or involve the use of any animal or human data etc.

\section{Consent to Participate}

Authors have agreed for authorship, read and approved the manuscript, and given consent for submission of the manuscript.

\section{Consent to Publish}

Authors have given consent for subsequent publication of the manuscript.

\section{Funding}

The funding is not applicable to this research.

\section{Competing Interests}

The authors do not have any competing interest.

\section{Availability of data and materials}

The data will be provided upon a reasonable request to corresponding author.

\section{Authors Contributions}

Rabia Akram: Abstract, Introduction, Literature Review, Conclusion.

Zeeshan Fareed: Data analysis, Writing results and discussion, Methodology.

Gan Xiaoli: Conceptualization, Supervision.

Bushra Zulfiqar: Supervision, Proofreading and Editing.

Farrukh Shahzad: Conceptualization, Data curation, Conclusion.

\section{References}

Acharyya, J. (2009). FDI, growth and the environment: Evidence from India on CO2 emission during the last two decades. Journal of economic development, 34(1), 43.

Al-mulali, U. (2012). Factors affecting CO2 emission in the Middle East: A panel data analysis. Energy, 44(1), 564-569.

Al-Mulali, U., Saboori, B., \& Ozturk, I. (2015a). Investigating the environmental Kuznets curve hypothesis in Vietnam. Energy Policy, 76, 123-131.

Al-Mulali, U., \& Tang, C. F. (2013). Investigating the validity of pollution haven hypothesis in the gulf cooperation council (GCC) countries. Energy Policy, 60, 813-819.

Al-Mulali, U., Weng-Wai, C., Sheau-Ting, L., \& Mohammed, A. H. (2015b). Investigating the environmental Kuznets curve (EKC) hypothesis by utilizing the ecological footprint as an indicator of environmental degradation. Ecological Indicators, 48, 315-323.

Allard, A., Takman, J., Uddin, G. S., \& Ahmed, A. (2018). The N-shaped environmental Kuznets curve: an empirical evaluation using a panel quantile regression approach. Environmental Science and Pollution Research, 25(6), 5848-5861. 
Ang, J. B. (2007). CO2 emissions, energy consumption, and output in France. Energy Policy, 35(10), 47724778.

Anoruo, E. (2011). Testing for linear and nonlinear causality between crude oil price changes and stock market returns. International Journal of Economic Sciences and Applied Research, 4(3), 75-92.

Apergis, N., Can, M., Gozgor, G., \& Lau, C. K. M. (2018). Effects of export concentration on CO 2 emissions in developed countries: an empirical analysis. Environmental Science and Pollution Research, 25(14), 14106-14116.

Arain, H., Han, L., Sharif, A., \& Meo, M. S. (2019). Investigating the effect of inbound tourism on FDI: The importance of quantile estimations. Tourism Economics, 1354816619859695.

Azomahou, T., Laisney, F., \& Van, P. N. (2006). Economic development and CO2 emissions: a nonparametric panel approach. Journal of public economics, 90(6-7), 1347-1363.

Baumol, W. J. (1971). Environmental protection, international spillovers and trade.

Behera, S. R., \& Dash, D. P. (2017). The effect of urbanization, energy consumption, and foreign direct investment on the carbon dioxide emission in the SSEA (South and Southeast Asian) region. Renewable and Sustainable Energy Reviews, 70, 96-106.

Behmiri, N. B., \& Manera, M. (2015). The role of outliers and oil price shocks on volatility of metal prices. Resources Policy, 46, 139-150.

Brajer, V., Mead, R. W., \& Xiao, F. (2011). Searching for an Environmental Kuznets Curve in China's air pollution. China Economic Review, 22(3), 383-397.

Chang, M.-C., \& Hu, J.-L. (2018). A long-term meta-frontier analysis of energy and emission efficiencies between G7 and BRICS. Energy Efficiency, 1-15.

Cheng, Z., Li, L., \& Liu, J. (2017). The emissions reduction effect and technical progress effect of environmental regulation policy tools. Journal of Cleaner Production, 149, 191-205.

Cho, J. S., Kim, T.-H., \& Shin, Y. (2015). Quantile cointegration in the autoregressive distributed-lag modeling framework. Journal of Econometrics, 188(1), 281-300.

Cole, M. A. (2004). Trade, the pollution haven hypothesis and the environmental Kuznets curve: examining the linkages. Ecological economics, 48(1), 71-81.

Cole, M. A., \& Elliott, R. J. (2005). FDI and the capital intensity of "dirty" sectors: a missing piece of the pollution haven puzzle. Review of Development Economics, 9(4), 530-548.

Cole, M. A., Elliott, R. J., \& Zhang, J. (2011). Growth, foreign direct investment, and the environment: evidence from Chinese cities. Journal of Regional Science, 51(1), 121-138.

Crocker, T. (1966). The structuring of atmospheric pollution control systems. The economics of air pollution. The economics of air pollution. New York, WW Norton \& Co, 61-86.

Destek, M. A., \& Sarkodie, S. A. (2019). Investigation of environmental Kuznets curve for ecological footprint: the role of energy and financial development. Science of the Total Environment, 650, 2483-2489.

Dong, K., Sun, R., \& Dong, X. (2018a). CO2 emissions, natural gas and renewables, economic growth: assessing the evidence from China. Science of the Total Environment, 640, 293-302.

Dong, K., Sun, R., Jiang, H., \& Zeng, X. (2018b). CO2 emissions, economic growth, and the environmental Kuznets curve in China: What roles can nuclear energy and renewable energy play? Journal of Cleaner Production, 196, 51-63.

Dutta, A., Bouri, E., \& Roubaud, D. (2019). Nonlinear relationships amongst the implied volatilities of crude oil and precious metals. Resources Policy, 61, 473-478.

Eskeland, G. A., \& Harrison, A. E. (2002). Moving to greener pastures? Multinationals and the pollution haven hypothesis. Retrieved from

Galeotti, M., Lanza, A., \& Pauli, F. (2006). Reassessing the environmental Kuznets curve for $\mathrm{CO} 2$ emissions: A robustness exercise. Ecological economics, 57(1), 152-163. 
Galvao , A. F. (2009). Unit root quantile autoregression testing using covariates. Journal of Econometrics, 152(2), 165-178.

Gill, Viswanathan, K. K., \& Hassan, S. (2018a). The Environmental Kuznets Curve (EKC) and the environmental problem of the day. Renewable and Sustainable Energy Reviews, 81, 1636-1642.

Gill, Viswanathan, K. K., \& Karim, M. Z. A. (2018b). The Critical Review of the Pollution Haven Hypothesis (PHH). International Journal of Energy Economics and Policy, 8(1), 167-174.

Govindaraju, V. C., \& Tang, C. F. (2013). The dynamic links between CO2 emissions, economic growth and coal consumption in China and India. Applied Energy, 104, 310-318.

Grossman, G. M., \& Helpman, E. (1993). The politics of free trade agreements. Retrieved from

Grossman, G. M., \& Krueger, A. B. (1991). Environmental impacts of a North American free trade agreement. Retrieved from

Grossman, G. M., \& Krueger, A. B. (1995). Economic growth and the environment. The quarterly journal of economics, $110(2)$, 353-377.

Hakimi, A., \& Hamdi, H. (2016). Trade liberalization, FDI inflows, environmental quality and economic growth: a comparative analysis between Tunisia and Morocco. Renewable and Sustainable Energy Reviews, 58, 1445-1456.

Halicioglu, F. (2009). An econometric study of $\mathrm{CO} 2$ emissions, energy consumption, income and foreign trade in Turkey. Energy Policy, 37(3), 1156-1164.

Hao, Y., Wu, Y., Wang, L., \& Huang, J. (2018). Re-examine environmental Kuznets curve in China: Spatial estimations using environmental quality index. Sustainable Cities and Society, 42, 498-511.

$\mathrm{He}$, J. (2006). Pollution haven hypothesis and environmental impacts of foreign direct investment: The case of industrial emission of sulfur dioxide (SO2) in Chinese provinces. Ecological economics, 60(1), 228-245.

He, J. (2011). Pollution haven hypothesis and Environmental impacts of foreign direct investment: The Case of Industrial Emission of Sulfur Dioxide (SO2) in Chinese provinces.

$\mathrm{He}, \mathrm{X} .$, \& Yao, X. (2017). Foreign direct investments and the environmental Kuznets curve: new evidence from Chinese provinces. Emerging Markets Finance and Trade, 53(1), 12-25.

Hitam, M. B., \& Borhan, H. B. (2012). FDI, growth and the environment: impact on quality of life in Malaysia. Procedia-Social and Behavioral Sciences, 50, 333-342.

Hoffmann, R., Lee, C. G., Ramasamy, B., \& Yeung, M. (2005). FDI and pollution: a granger causality test using panel data. Journal of International Development: The Journal of the Development Studies Association, 17(3), 311-317.

Jalil, A., \& Feridun, M. (2011). The impact of growth, energy and financial development on the environment in China: a cointegration analysis. Energy Economics, 33(2), 284-291.

Jalil, A., \& Mahmud, S. F. (2009). Environment Kuznets curve for CO2 emissions: a cointegration analysis for China. Energy Policy, 37(12), 5167-5172.

Javorcik, B. S., \& Wei, S.-J. (2004). Pollution havens and foreign direct investment: dirty secret or popular myth? Contributions in Economic Analysis \& Policy, 3(2).

Jiang, Y., Lin, T., \& Zhuang, J. (2011). Environmental Kuznets Curves in the People's Republic of China: turning points and regional differences.

Kahneman, D., \& Tversky, A. (2013). Prospect theory: An analysis of decision under risk Handbook of the fundamentals of financial decision making: Part I (pp. 99-127): World Scientific.

Kharbach, M., \& Chfadi, T. (2017). CO2 emissions in Moroccan road transport sector: Divisia, Cointegration, and EKC analyses. Sustainable Cities and Society, 35, 396-401.

Kim, T.-H., \& White, H. (2003). Estimation, inference, and specification testing for possibly misspecified quantile regression Maximum likelihood estimation of misspecified models: twenty years later (pp. 107-132): Emerald Group Publishing Limited. 
Kirkpatrick, C., \& Shimamoto, K. (2008). The effect of environmental regulation on the locational choice of Japanese foreign direct investment. Applied Economics, 40(11), 1399-1409.

Koenker, R., \& Xiao, Z. (2004). Unit root quantile autoregression inference. Journal of the American Statistical Association, 99(467), 775-787.

Kumar, S. (2017). On the nonlinear relation between crude oil and gold. Resources Policy, 51, 219-224.

Lahiani, A., Benkraiem, R., Miloudi, A., \& Shahbaz, M. (2018). New Evidence on the Relationship Between Crude Oil Consumption and Economic Growth in the US: A Quantile Causality and Cointegration Approach. Journal of Quantitative Economics, 1-24.

Lee, J. W. (2013). The contribution of foreign direct investment to clean energy use, carbon emissions and economic growth. Energy Policy, 55, 483-489.

Liu, K., \& Lin, B. (2019). Research on influencing factors of environmental pollution in China: A spatial econometric analysis. Journal of Cleaner Production, 206, 356-364.

Low, P., \& Yeats, A. (1992). Do" dirty" industries migrate? World Bank Discussion Papers[WORLD BANK DISCUSSION PAPER.]. 1992.

Michieka, N. M., Fletcher, J., \& Burnett, W. (2013). An empirical analysis of the role of China's exports on CO2 emissions. Applied Energy, 104, 258-267.

Mundial, B. (2007). Cost of pollution in China: economic estimates of physical damages Cost of pollution in China: economic estimates of physical damages: Banco Mundial.

Murthy, K., \& Gambhir, S. (2018). Analyzing Environmental Kuznets Curve and Pollution Haven Hypothesis in India in the Context of Domestic and Global Policy Change. Australasian Accounting, Business and Finance Journal, 12(2), 134-156.

Neequaye, N. A., \& Oladi, R. (2015). Environment, growth, and FDI revisited. International Review of Economics \& Finance, 39, 47-56.

Ngarambe, J., Lim, H. S., \& Kim, G. (2018). Light pollution: Is there an Environmental Kuznets Curve? Sustainable Cities and Society, 42, 337-343.

Özokcu, S., \& Özdemir, Ö. (2017). Economic growth, energy, and environmental Kuznets curve. Renewable and Sustainable Energy Reviews, 72, 639-647.

Ozturk, I., \& Acaravci, A. (2010). CO2 emissions, energy consumption and economic growth in Turkey. Renewable and Sustainable Energy Reviews, 14(9), 3220-3225.

Ozturk, I., \& Acaravci, A. (2013). The long-run and causal analysis of energy, growth, openness and financial development on carbon emissions in Turkey. Energy Economics, 36, 262-267.

Ozturk, I., \& Al-Mulali, U. (2015). Investigating the validity of the environmental Kuznets curve hypothesis in Cambodia. Ecological Indicators, 57, 324-330.

Pao, H.-T., \& Tsai, C.-M. (2010). CO2 emissions, energy consumption and economic growth in BRIC countries. Energy Policy, 38(12), 7850-7860.

Pao, H.-T., \& Tsai, C.-M. (2011). Multivariate Granger causality between CO2 emissions, energy consumption, FDI (foreign direct investment) and GDP (gross domestic product): evidence from a panel of BRIC (Brazil, Russian Federation, India, and China) countries. Energy, 36(1), 685-693.

Pesaran, M. H., Shin, Y., \& Smith, R. J. (2001). Bounds testing approaches to the analysis of level relationships. Journal of applied econometrics, 16(3), 289-326.

Po, W.-C., \& Huang, B.-N. (2008). Tourism development and economic growth-a nonlinear approach. Physica A: Statistical mechanics and its applications, 387(22), 5535-5542.

Salman, M., Long, X., Dauda, L., Mensah, C. N., \& Muhammad, S. (2019). Different impacts of export and import on carbon emissions across 7 ASEAN countries: A panel quantile regression approach. Science of the Total Environment, 686, 1019-1029.

Sari, R., \& Soytas, U. (2007). The growth of income and energy consumption in six developing countries. Energy Policy, 35(2), 889-898. 
Sarkodie, S. A., \& Strezov, V. (2018a). Empirical study of the Environmental Kuznets curve and Environmental Sustainability curve hypothesis for Australia, China, Ghana and USA. Journal of Cleaner Production, 201, 98-110.

Sarkodie, S. A., \& Strezov, V. (2018b). A review on Environmental Kuznets Curve hypothesis using bibliometric and meta-analysis. Science of the Total Environment.

Sarkodie, S. A., \& Strezov, V. (2019). Effect of foreign direct investments, economic development and energy consumption on greenhouse gas emissions in developing countries. Science of the Total Environment, 646, 862-871.

Shahbaz, M., Dube, S., Ozturk, I., \& Jalil, A. (2015). Testing the environmental Kuznets curve hypothesis in Portugal. International Journal of Energy Economics and Policy, 5(2), 475-481.

Shahbaz, M., Lahiani, A., Abosedra, S., \& Hammoudeh, S. (2018). The role of globalization in energy consumption: a quantile cointegrating regression approach. Energy Economics, 71, 161-170.

Stern, D. I., \& Common, M. S. (2001). Is there an environmental Kuznets curve for sulfur? Journal of Environmental Economics and Management, 41(2), 162-178.

Sun, C., Zhang, F., \& Xu, M. (2017). Investigation of pollution haven hypothesis for China: an ARDL approach with breakpoint unit root tests. Journal of Cleaner Production, 161, 153-164.

Tamazian, A., Chousa, J. P., \& Vadlamannati, K. C. (2009). Does higher economic and financial development lead to environmental degradation: evidence from BRIC countries. Energy Policy, 37(1), 246-253.

Tamazian, A., \& Rao, B. B. (2010). Do economic, financial and institutional developments matter for environmental degradation? Evidence from transitional economies. Energy Economics, 32(1), 137-145.

Tollefson, J. (2017). World's carbon emissions set to spike by 2\% in 2017. Nature News, 551(7680), 283.

United Nations (Producer). (2018). China Meets 2020 Carbon Target Three Years Ahead of Schedule [Press release]. Retrieved from https://unfccc.int/news/china-meets-2020-carbon-target-three-yearsahead-of-schedule

Vollebergh, H. R., \& Kemfert, C. (2005). The role of technological change for a sustainable development: Elsevier.

Walter, I., \& Ugelow, J. L. (1979). Environmental policies in developing countries. Ambio, 102-109.

Wang, S., Zhou, D., Zhou, P., \& Wang, Q. (2011). CO2 emissions, energy consumption and economic growth in China: A panel data analysis. Energy Policy, 39(9), 4870-4875.

Wang, X., Sun, C., Wang, S., Zhang, Z., \& Zou, W. (2018). Going green or going away? A spatial empirical examination of the relationship between environmental regulations, biased technological progress, and green total factor productivity. International journal of environmental research and public health, 15(9), 1917.

Wang, Y., Zhang, C., Lu, A., Li, L., He, Y., ToJo, J., \& Zhu, X. (2017). A disaggregated analysis of the environmental Kuznets curve for industrial CO2 emissions in China. Applied Energy, 190, 172-180.

Wang, Z., Li, C., Liu, Q., Niu, B., Peng, S., Deng, L., . . . Zhang, X. (2019). Pollution haven hypothesis of domestic trade in China: A perspective of SO2 emissions. Science of the Total Environment, 663, 198-205.

World Bank. (2018). [https://data.worldbank.org/indicator].

World energy outlook. (2010). World energy outlook 2010. International Energy Agency, 1(3).

Xiao, Z. (2015). An empirical test of the pollution haven hypothesis for China: intra-host country analysis. Nankai Business Review International, 6(2), 177-198.

$\mathrm{Xu}, \mathrm{T}$. (2018). Investigating environmental Kuznets curve in China-aggregation bias and policy implications. Energy Policy, 114, 315-322.

$\mathrm{Xu}, \mathrm{X}$. (1999). Do stringent environmental regulations reduce the international competitiveness of environmentally sensitive goods? A global perspective. World Development, 27(7), 1215-1226. 
671

672

673

674

675

676

677

678

679

680

681

682

683

684

685

686

687

688

689

690
Zakarya, G. Y., Mostefa, B., Abbes, S. M., \& Seghir, G. M. (2015). Factors affecting CO2 emissions in the BRICS countries: a panel data analysis. Procedia Economics and Finance, 26, 114-125.

Zhang, C., \& Zhou, X. (2016). Does foreign direct investment lead to lower CO2 emissions? Evidence from a regional analysis in China. Renewable and Sustainable Energy Reviews, 58, 943-951.

Zhang, J., Luo, M., \& Cao, S. (2018). How deep is China's environmental Kuznets curve? An analysis based on ecological restoration under the Grain for Green program. Land Use Policy, 70, 647-653.

Zheng, J., \& Sheng, P. (2017). The impact of foreign direct investment (FDI) on the environment: market perspectives and evidence from China. Economies, 5(1), 8.

Zhou, Y., Sirisrisakulchai, J., Liu, J., \& Sriboonchitta, S. (2018). The impact of economic growth and energy consumption on carbon emissions: evidence from panel quantile regression. Paper presented at the Journal of Physics: Conference Series.

Zhu, H., Duan, L., Guo, Y., \& Yu, K. (2016a). The effects of FDI, economic growth and energy consumption on carbon emissions in ASEAN-5: evidence from panel quantile regression. Economic Modelling, $58,237-248$.

Zhu, H., Peng, C., \& You, W. (2016b). Quantile behaviour of cointegration between silver and gold prices. Finance Research Letters, 19, 119-125.

Zivot, E., \& Andrews, D. W. K. (2002). Further evidence on the great crash, the oil-price shock, and the unit-root hypothesis. Journal of business \& economic statistics, 20(1), 25-44. 
Figures

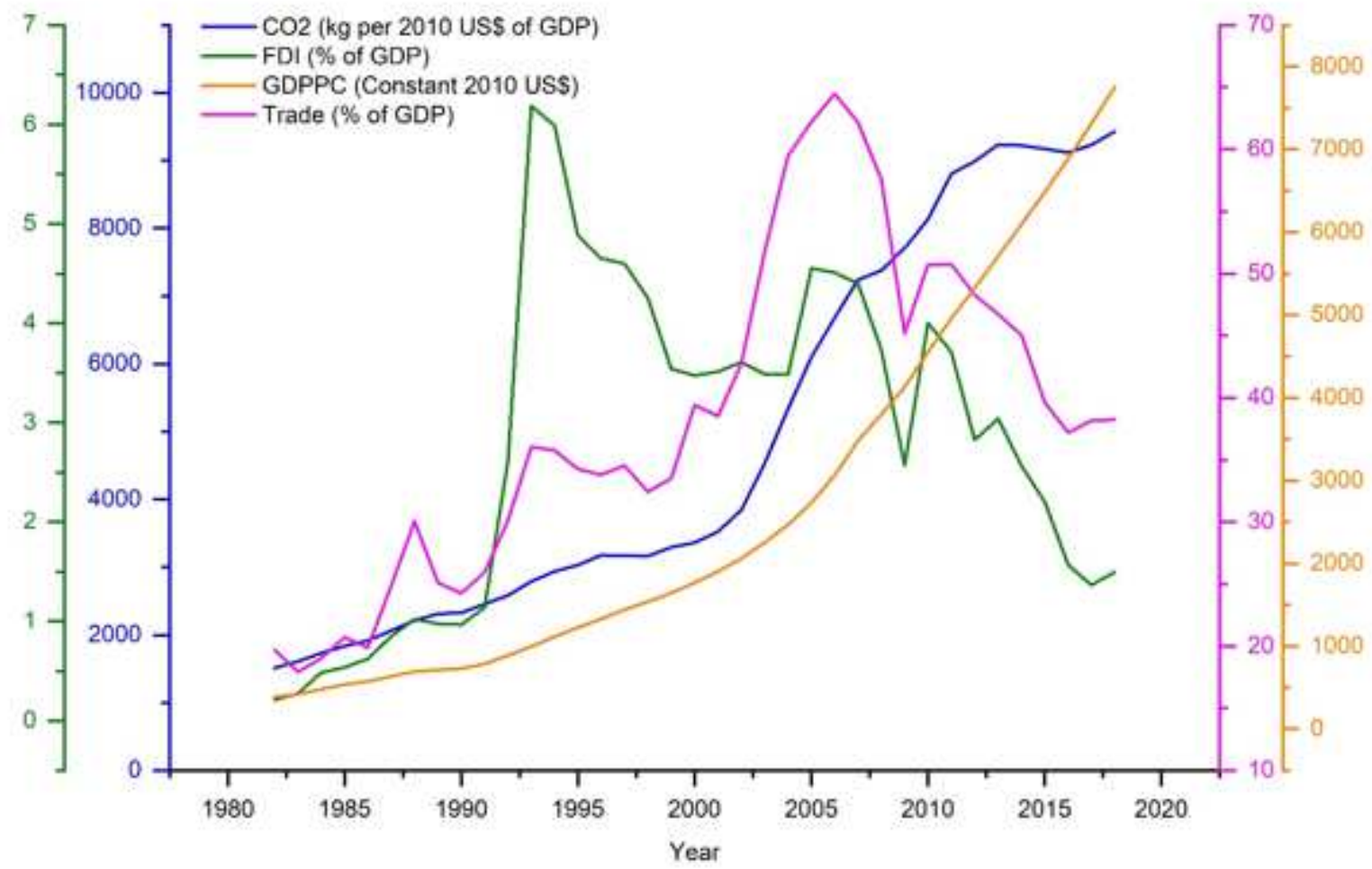

Figure 1

Yearly time trend of CO2, GDP, FDI and Trade in China
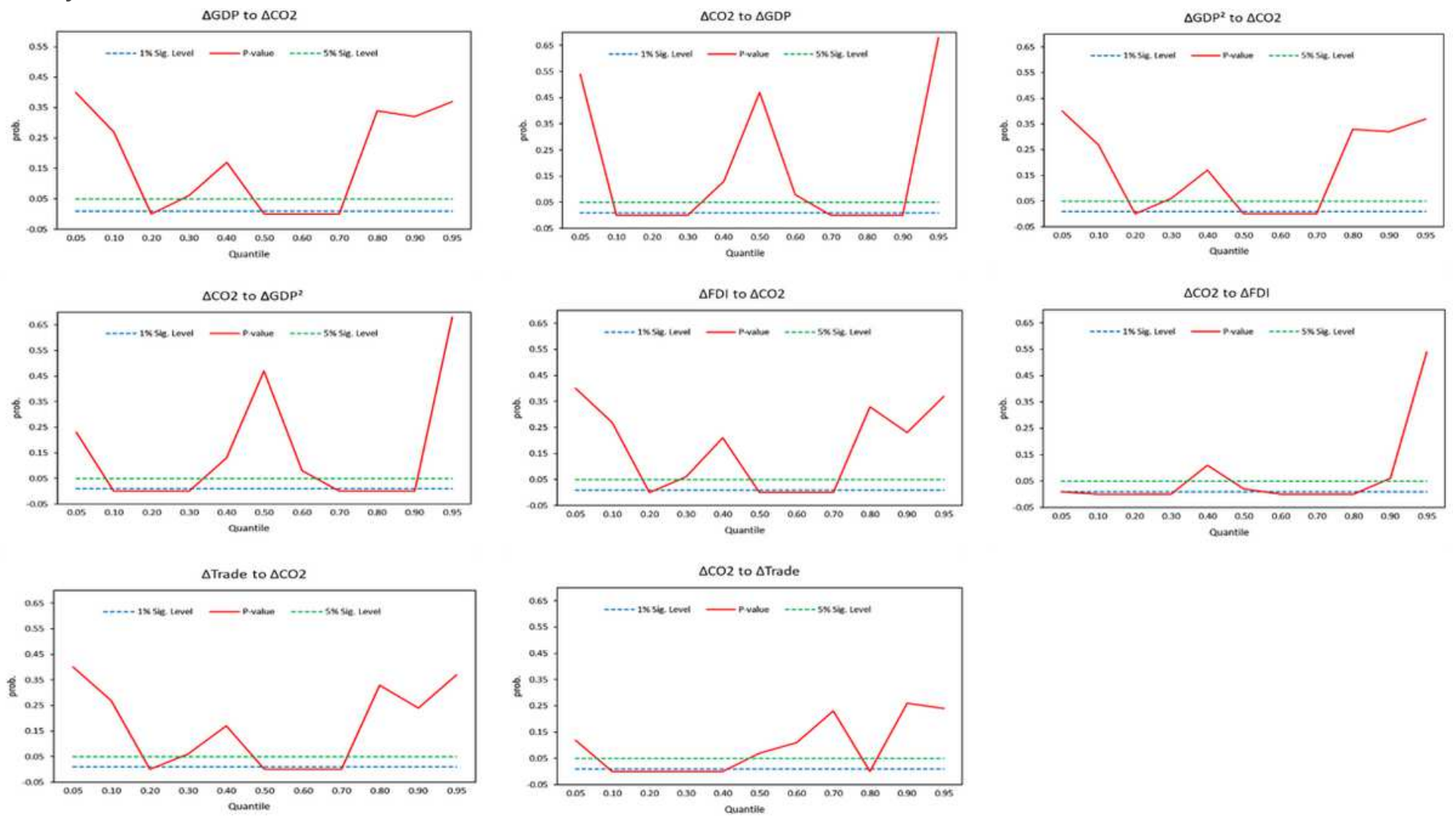
Figure 2

Graphs of quantile Granger causality results

\section{Supplementary Files}

This is a list of supplementary files associated with this preprint. Click to download.

- Table4andTable6.docx 